Article

\title{
The Circular Economy Concept in Design Education: Enhancing Understanding and Innovation by Means of Situated Learning
}

\author{
Alexander Wandl ${ }^{1, *}$, Verena Balz ${ }^{1}$, Lei Qu ${ }^{1}$, Cecilia Furlan ${ }^{1}$, Gustavo Arciniegas ${ }^{1,2}$ and Ulf Hackauf ${ }^{1}$ \\ ${ }^{1}$ Department of Urbanism, Faculty of Architecture, Delft University of Technology, 2628 BL Delft, The Netherlands; \\ E-Mails: a.wandl@tudelft.nl (A.W.), v.e.balz@tudelft.nl (V.B.), I.qu@tudelft.nl (L.Q.), c.furlan@tudelft.nl (C.F.), \\ u.d.hackauf@tudelft.nl (U.H.) \\ ${ }^{2}$ Geo-Col GIS and Collaborative Planning-REPAiR Project, 2628 JT Delft, The Netherlands; \\ E-Mail: geocolconsultant@gmail.com \\ * Corresponding author
}

Submitted: 31 March 2019 | Accepted: 25 June 2019 | Published: 27 September 2019

\begin{abstract}
The concept of circular economy (CE) is high on the agenda of many planning agencies in European countries. It has also become a prominent issue in European academic education institutions. It is expected that spatial planning and design can support and add the spatial quality dimension of such a transition towards CE. However, incorporating the concept of $C E$ in an integrative manner in urban design and planning courses is challenging because of its metabolic and complex nature. This article presents the first results of integrating design-teaching activities at a faculty of architecture with an $\mathrm{H} 2020$-financed research project. The integration of research and design education provided the students with a situated and indeed transdisciplinary learning environment. Students understood that they needed to address challenges from a systemic perspective rather early in the design process, meaning to understand what the relations between different subsystems and their spatial structures are. Furthermore, the experiment provided evidence that the eco-innovative solutions developed by the students are seen as an effective option to achieve objectives for a transition towards CE by stakeholders.
\end{abstract}

\section{Keywords}

Amsterdam Metropolitan Area; circular economy; design education; situated learning; urban design

Issue

This article is part of the issue "Facilitating Circular Economy in Urban Planning", edited by Hilde Remoy (Delft University of Technology, The Netherlands), Alexander Wandl (Delft University of Technology, The Netherlands) and Denis Ceric (Polish Academy of Sciences, Poland).

(C) 2019 by the authors; licensee Cogitatio (Lisbon, Portugal). This article is licensed under a Creative Commons Attribution 4.0 International License (CC BY).

\section{Introduction}

The Circular Economy (CE) concept is high on the agenda of planning agencies in cities and regions across European countries. It has also become a prominent issue in academic education at several European schools. It is expected that spatial planning and design can add the spatial quality dimension of a transition towards CE. To achieve this and equip present and future urbanists with the knowledge and skills required to fulfil this expectation, adaptations of current teaching practices must be implemented. As Dehaene (2018) stated, the challenges that are related to "water, energy, nutrient and soil cycles, as well as localised food production, are rather new to urbanists, who traditionally focus on housing and mobility".

Furthermore, it also requires a critical consideration and further development of concepts that are normally at the core of CE strategies, with a focus on closed-loop industrial symbiosis and the development of CE business cases and circular service-based economies. We agree with Williams (2019) that "the current conceptualisation 
for the CE is inadequate when applied to a city" or region. She identified five crucial issues of this inadequateness: (1) the fact that the city, contrary to industrial processes, is a complex, self-organising system, where economy is an important factor, but not the dominant one; (2) the focus of CE approaches on the production side of the value chain and the underrepresentation of the need for sustainable consumption patterns as crucial aspect for the transition towards a CE; (3) the exclusion of land as a resource although it is one of the most valuable resources of regions; (4) the neglecting of infrastructure, both as a resource, but also as an instrument to steer circular policies; and (5) that the dominant approach ignores the importance of different scales for closing resource loops. One way to overcome these inadequacies is to better integrate (van der Leer, van Timmeren, \& Wandl, 2018) and further develop principles of CE with regional planning and design, plans, and policies.

However, this requires an integration of expertise on resource flows and industrial processes in the practice of spatial planning and design and calls for transdisciplinary learning approaches in urban and regional design education. This is a general challenge in the field of Urbanism also concerning other issues with urgent societal relevance, like climate adaptation. The TU Delft-led Horizon 2020 project REPAiR-Resource Management in Peri-Urban Areas, which has the core aim to integrate spatial development and resource flow management, provided the possibility to develop, test, and assess adapted ways of teaching and situated learning. This happened in two courses that are both included in the MSc programme of the Faculty of Architecture and the Built Environment: one compulsory design studio and one elective design course. This article reports on the first two years of this pilot, answering the following two research questions:

(1) What teaching activities have been developed and implemented to provide knowledge and skills, and to what extent has this integration of CE and design education been understood by students, and further contributed to innovative solutions for the transition towards CE?

(2) To what extent were the proposals developed by the students appreciated by the stakeholders?

The questions were answered by conducting a case study on two MSc courses during the academic years of 2017 and 2018. The case study is built up in three sections, which also structure the remainder of this article.

First, there is a description of the courses and how they were adapted. Second, an analysis of the students' results by the course coordinators answering the following questions:

(1) Did students integrate multiple concepts?

(2) Did students develop a spatial understanding of resource flows?
(3) Did the students understand the physical footprint and impact on the spatial quality of the linear as well as a proposed CE?

(4) Were students able to describe, understand, and propose an alteration to systemic relationships?

Third, the validation of the outcome of the teaching experiments, using the feedback received from questionnaires distributed by student organisations, tutors' meetings and interviews with stakeholders, as well as regional stakeholder feedback collected by the REPAiR project during the Peri-urban living lab process conducted in the Amsterdam Metropolitan Area (AMA).

\section{Integration of Research into Design Education}

Inspired by the idea of enhancing regional collaboration in education, highlighted in the Strategic Agenda for Higher Education and Research (2015-2025, published by the Dutch Ministry of Education, Culture and Science in 2015), there is an increasing ambition in Urbanism education at Delft University of Technology to collaborate with research projects to offer rich learning environments. The aim of the integration of research and education is twofold. From the research projects perspective, the integration of student education should allow to test the research methods and find innovative solutions for the research projects' main outcome. From the education perspective, the connection to an on-going research project should provide state-of-the-art knowledge and insight into scientific research and provide transdisciplinary learning environments.

However, there are challenges to achieving such integration. The aim of the research is to develop beyond the state of the art, while education focuses on transferring the state-of-the-art knowledge. Moreover, the field of circularity is complex and its integration in the equally complex field of spatial design raises the level of difficulty for the students and even the teachers, let alone that fact that the CE field is still in development and, teachers need to transfer knowledge that is still dynamic.

These challenges were overcome in the design education by collaborating with researchers, who are at the forefront of knowledge generation and transfer, as well as integrating the teaching activities in the living labs established by the research project. In this way, a learning environment with the support of the established regional and sectoral stakeholders in practice is provided. This is a "situated learning" environment that provides chances for students to participate in the "community of practice" (Lave \& Wenger, 1991), which has its relevance to design education (Lawson \& Dorst, 2009). What can be expected includes: (1) an enhanced problem definition and assignment of the course through early consultation of societal partners, resulting in more relevant student work; (2) a more structured and substantial participation of societal partners in education, resulting in more exchange between students, researchers and societal part- 
ners; and (3) an enhanced valorisation of student work via partner institutes, resulting in more publication and active engagement of students in societal debate.

In situated learning, students play a role not as a passive audience, but as inventors and advocates of best practices (de Hei, 2016; Schweitzer, Howard, \& Doran, 2008). Such an approach seeks innovation in Urbanism education by better preparing students for the collaboration and negotiation involved in their future professions. To achieve this goal, as pointed out by Müller, Tjallingii and Canters (2005), a transdisciplinary context that reflects real-life settings should complement disciplinary specialisation. Settings resembling "urban living labs" (Steen \& Van Bueren, 2017) are particularly required in regional design education because they reflect the, at times, contested multi-actor setting of the practice.

The following sections explain how the situated learning environment was set up for two courses, the learning outcomes concerning the issue of integrating aspects of different fields of expertise and the assessment of student projects by the stakeholders.

\section{Adapting Urbanism Education}

Urbanism is concerned with understanding the spatial organisation and dynamics of the built environment and inventing new ways to maintain spatial quality and equality. Urbanism is a scientific design education, characterised by the interaction between thinking (analysis and reflection) and doing (the speculative/intuitive imagination of spatial interventions). Starting with the spring Semester 2017, the integration of CE as a topic was tested in two urbanism courses in a situated learning environment:

(1) MSc course "Spatial Strategies for the Global Metropolis", an obligatory annual course of the MSc Urbanism programme that integrated CE in 2017 and 2018, each with about 75 students;

(2) MSc course "Geodesign for a Circular Economy in Urban Regions", an elective course open to students of different MSc programmes that ran in 2017 and 2018, each with about 15 students.

Common adaptations to both courses were that the students were introduced to a definition of $C E$, which already included aspects of spatial quality and spatial development, and therefore went beyond definitions they might have been familiar with:

Circular Economy (REPAiR-specific): An economy that accommodates resources to flow through humanmade and natural systems in renewable ways, creating or retaining value through "slowed, closed or narrowed loops/flows", rather than rapidly destructing value through the creation of waste. This value can manifest itself in monetary principles as well as other social, ecological or economic principles, taking account of potential trade-offs. Important in this notion is the establishment of production-consumptionuse systems built on restorative resources in optimal flows. By optimal flows, it is implied that cycles are closed or connected in spatially and temporally favourable conditions, i.e., where and when is most appropriate (highest possible value, possibly via cascading loops). Moreover, changes in one part of the system should not incite negative externalities. Of particular interest for REPAiR in this respect are the impacts on spatial quality. From that perspective, REPAiR also takes the notion of wastescapes (open spaces as well as built urban form) into consideration. (Geldermans \& Taelman, 2016)

Moreover, students were introduced to two resource flows that were previously identified as key flows by the local stakeholders: food waste, and construction and demolition waste. The following subsections provide, for both courses respectively, a general description of the course followed by the manner in which the courses addressed the challenges defined above.

\subsection{Urbanism MSC Course "Spatial Strategies for the Global Metropolis"}

Regional design is the core theme of the third quarter of the MSc Urbanism curriculum and deals with promoting solutions to long-term challenges in a given Dutch regional context. It emphasises on a comprehensive, evidence-informed understanding of regional spatial structures and development trends, as well as an understanding of interrelations between design, planning, and politics. The design process leads to two products, a spatial vision and the development strategy. Since 2017, this course has been conducted in collaboration with the REPAiR project, focusing on regional design for the AMA, and stimulating its transition towards a CE.

The learning goals of the course remain the same each year, but when integrating the course with the REPAiR project, some of the learning goals have been more specifically oriented towards the theme of CE. Students are expected to show, in their regional design proposals, a deep understanding of CE and its spatial implications. By the end of the course, students are expected to be able to (1) understand the complexity, multi-scalarity, and uncertainty of regional spatial development; (2) consider the limitations that these conditions set to regional planning and design; and (3) formulate and argue for a comprehensive regional vision. Students were expected to conduct systematic analyses on material flows at the regional scale and identify the spatial implications of such flows and the societal relevance of the CE concepts. As output, the students formulate an innovative vision, which comprehensively integrates correlated development and normative goals.

The Research and Design Studio is the core activity of this course. Students conduct a regional design in groups 
of 4 to 5 students, supervised by two tutors with complementary expertise on planning, design, and CE. As the duration of the course is only 10 weeks, and the level of complexity involved is very high, predefined themes are provided to guide the studio work: reuse of land, energy, water, and waste. Supporting course elements are an integral part of the studio, providing knowledge about theories and methods of regional analysis and design with lectures and workshops. Furthermore, the REPAiR team developed two half-day workshops, which were integrated into education. The first one-week 2-was intending to educate the students in an urban metabolismbased method for system analysis and system design. This method is based on the Netzstadt approach (Baccini \& Oswald, 2008) and combines urban morphological as well as urban physiological methods to understand which spatial systems and their potential adaptations in a region are crucial to support the CE transition. The second one-week 6-introduced the students to a multisize (micro, meso, macro), multi-geoscale (processes located at different geographical scales), and multidisciplinary sustainability assessment framework (Taelman, Tonini, Wandl, \& Dewulf, 2018) for assessing and further developing their spatial strategy.

Additionally, the REPAiR team provided a lecture for the opening session, which introduced the basic concepts and theories behind CE as well as the global and regional circularity gap to emphasise the urgency of the CE transition. This input was complemented by lectures from planning practitioners-weeks 3 and $4-$ who shared their experience with CE projects. The students received stakeholder feedback twice during the course: at the midterm presentation, when the students presented their vision, and during the final review, when the students presented the spatial development strategy.

Equally important was to prepare and educate the teachers. The aim was not to make them CE experts, but rather to bring them up to date with CE challenges and $\mathrm{CE}$ related planning policies and initiatives within the AMA. This was achieved in a one-afternoon session, where key literature and policy documents were discussed. The teachers were also assured that in case of specific CE-related questions, the REPAiR mentors would be available for extra mentoring of student groups. Figure 1 shows a timeline of the activities that took place for the duration of the course.

\subsection{Elective Course: Geodesign for CE in Urban Regions}

This elective course was newly designed as a transdisciplinary course that tests methods developed within the research project under controlled and simplified circumstances and uses the creative potential of design students to inform research activities in the PeriUrban Living Labs (PULL). The course was attended by students following four different MSc programmes: urbanism, architecture, landscape architecture, and industrial ecology.

The course methodology builds upon the geodesign framework (Figure 2) of Steinitz (2012), which consists of three iterations of six questions and models that together are used to understand the study area, to develop methods for the study, and to perform the study (Figure 3). The course focuses on the third iteration to perform the study, which in this case means to develop and evaluate an eco-innovative solution (EIS) to support the transition towards a CE in the AMA. The students were introduced to the results of the first and second iteration, which were achieved by the REPAiR research team and the local stakeholders within a living lab environment (Russo et al., 2016). This means that the students were working within clearly defined methodological boundaries and a defined decision model.

The course is organised into three parts: introduction, study, and iteration (Figure 3). Additionally, the students take part in a workshop in one of the other case study areas of the REPAiR project. The introduction during the first weeks was used to familiarise the students

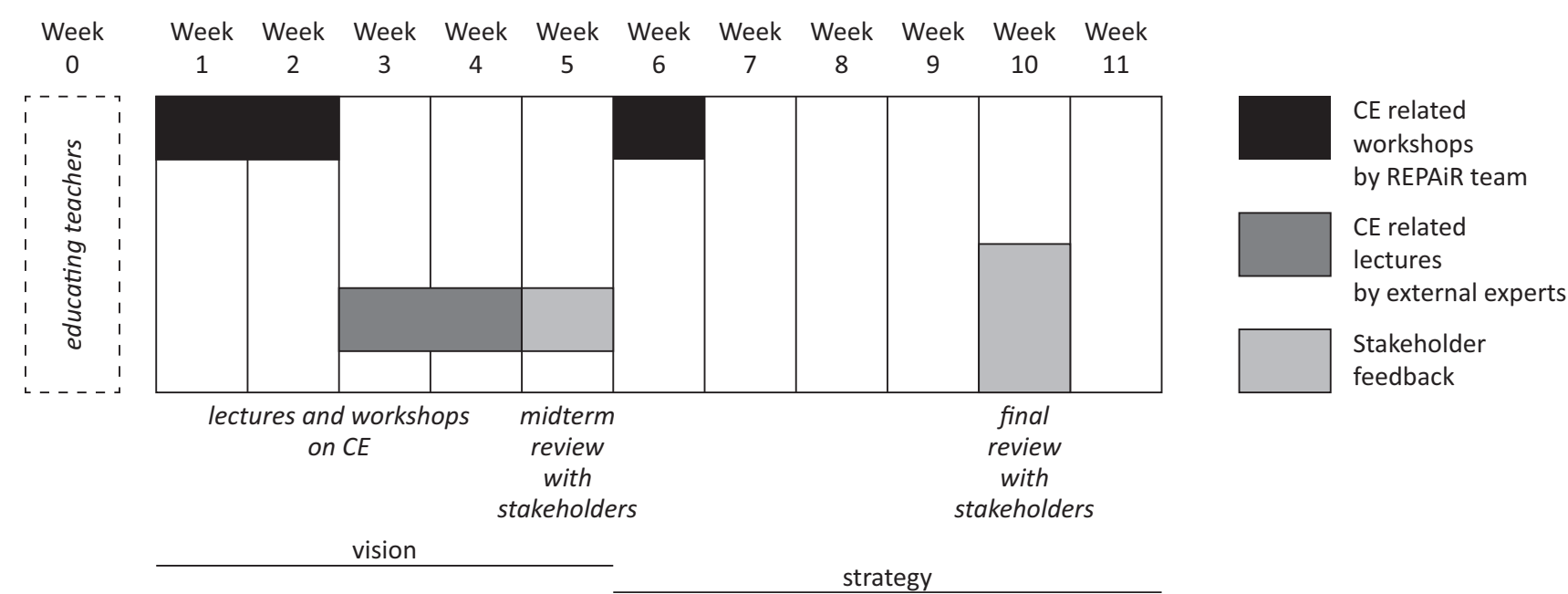

Figure 1. The simplified timeline of the Spatial Strategies for the Global Metropolis course illustrating the CE related input and stakeholder interaction. 


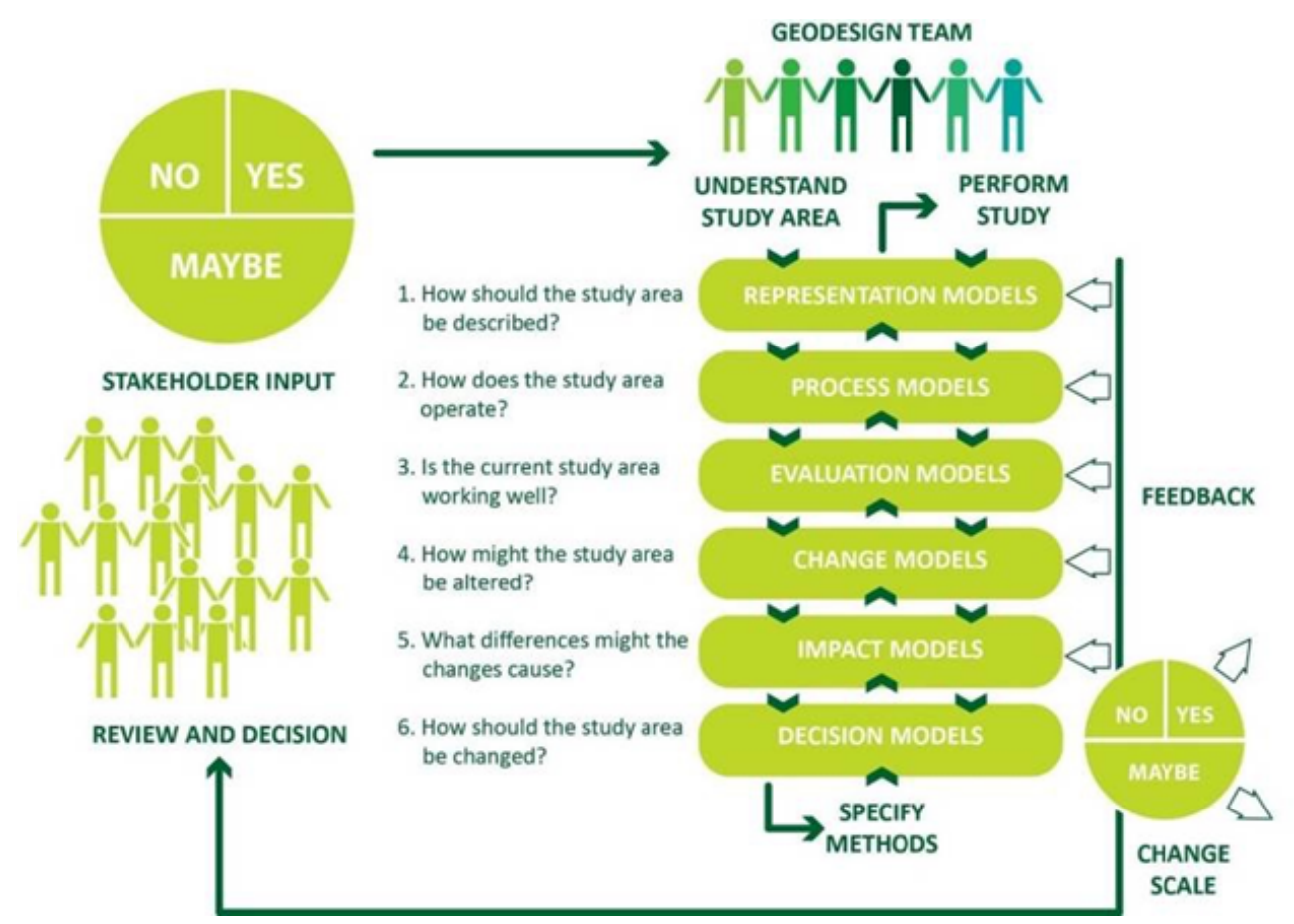

Figure 2. The structure of the geodesign framework of Steinitz (2012). Graphics by REPAiR researcher Libera Amenta.

with: (1) the basic concepts used during the course-CE, geodesign, EIS; (2) the case study area-the AMA; (3) the key flows identified by the stakeholders-construction and demolition waste, and food waste; and (4) the challenges defined by the stakeholders for the key flows. At the end of the week, the students had to formulate the first idea of one EIS. Based on this idea, the students were grouped in teams of three, always including one urbanism, one industrial ecology, and one architecture or landscape architecture student in each group. In this way, the interdisciplinary aspect was simulated.

The study phase extended over week 2 to 6 . Each week, the students were introduced to: (1) one model of the adapted geodesign framework; (2) theoretical back- ground; and (3) methods and tools they should use. In week 2, students were introduced to GIS supported system analyses and systemic design methods. In week 3, the input focused on urban metabolism-based sustainability assessment and related indicators. The students then directly applied their acquired knowledge by creating a first version of the respective model, adjusted to their EIS. Two to three teachers were present, supporting the students with methodological and conceptual help. Each step concluded with a group presentation and discussion.

The iteration phase took place over the last three weeks of the course. The students updated their EIS and the related models based on their findings from the

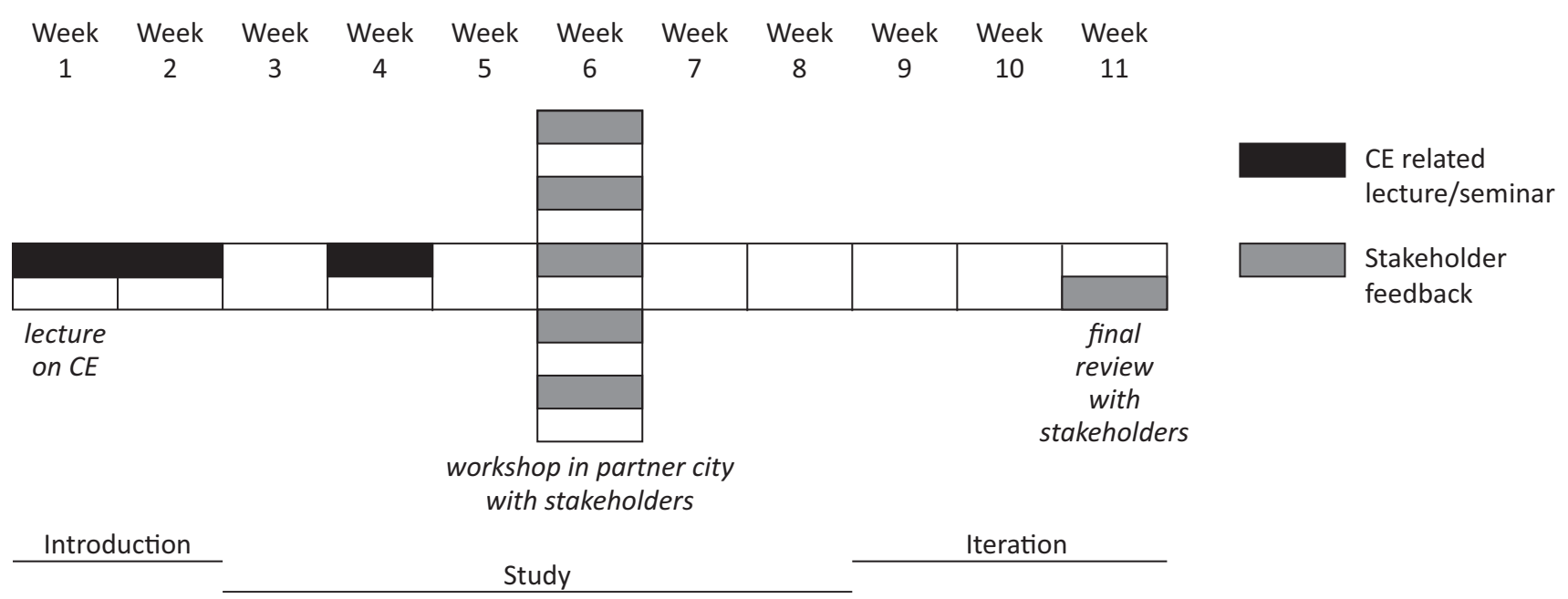

Figure 3. The simplified timeline of the course "Geodesign for a Circular Economy in Urban Regions" illustrating the CE related input and stakeholder interaction. 
previous phase and discussions with stakeholders or researchers from the REPAiR team. The iteration phase was interrupted by a week-long workshop in one of the other case study areas of the REPAiR project. These workshops were organised with the Università degli Studi di Napoli Federico II, in 2017, and the HafenCity University, in 2018. In the workshops, students from all three faculties worked together to quickly develop urban design proposals answering challenges and solution paths that were formulated and developed in the local living labs. The aim of these workshops was twofold, on the one hand, to make the students aware of the limitations of the transferability of EIS, but to understand on the other hand that the methods the students learned helped them to accelerate their design process. Moreover, students from foreign universities provided the living labs with an external perspective on local challenges.

The final week of the course was used to prepare a poster presentation. The presentation was used to give feedback to the students based on the course learning goals, but also to engage in a discussion on the overall findings of the REPAiR project. The poster format made it easy to show and discuss the results in later meetings with local stakeholders of the project.

During the course, it was important to define the meaning of eco-innovation in design terms and solutions together with the students. The awareness of moving towards circularity has raised the necessity to modify and renew existing technological production and sociopolitical, environmental, and economic behavioural patterns. Such awareness is developing alternative types of responses, the so-called solutions and strategies, to make the shift towards circularity.

The EIS is defined as an alternative course of action encompassing decisions on the following aspects (EC, 2011; Remoy, Furlan et al., 2018):

(1) The development and implementation of new materials, technologies, or processes in connection with the development of sustainable economic activities, or adding new activities in value chains with the modification of the status of the current waste management systems, and the resource flows, also capable of modifying the spatial configuration of peri-urban areas;

(2) The modification of existing policies and governance, or new policy/governance developments;

(3) The definition of spatial and environmental design proposals. These solutions will potentially lead to the modification of existing flows of materials, development of new flows and processes, and/or change the spatial design of areas, as well as generate change in the behaviour of stakeholders and inhabitants.

Strategies and solutions towards eco-innovation are normally used in the context of complex problems. Different disciplines have reflected upon alternative approaches related to different parts of the problem-solving process. Engineering disciplines are used to optimise processes when both solutions and objectives are well defined, while designers usually work in contexts where neither of those is well defined, using design to reveal new possibilities. In this light, the proposals of the students are situated within the innovation realm, where problems and objectives were defined within the Living Lab workshops but the solution was not (Figure 4).

\section{Discussion of Outcomes}

In total, around 200 students participated in the two courses. The following subsection discusses exemplary student results to answer the research question: To what extent has this integration of CE and design education been understood by students, and further contributed to innovative solutions?

In doing so, we assess the results according to the following aspects:

(1) Did students integrate multiple concepts?

(2) Did students develop a spatial understanding of resource flows?

\begin{tabular}{|c|c|c|c|}
\hline \multirow{2}{*}{\multicolumn{2}{|c|}{$\begin{array}{c}\text { DIFFERENT } \\
\text { APPROACHES TO } \\
\text { ADDRESS COMPLEX } \\
\text { PROBLEMS }\end{array}$}} & \multicolumn{2}{|c|}{ Are the problems and objectives defined? } \\
\hline & & \multirow{2}{*}{$\begin{array}{c}\text { YES } \\
\text { Optimisation }\end{array}$} & \multirow{2}{*}{$\begin{array}{c}\text { NO } \\
\text { Negotiation }\end{array}$} \\
\hline \multirow{2}{*}{$\begin{array}{c}\text { Are the solutions } \\
\text { defined? }\end{array}$} & YES & & \\
\hline & NO & $\begin{array}{l}\text { Innovation } \\
i\end{array}$ & Design \\
\hline & & blended & REPAIR \\
\hline
\end{tabular}

Figure 4. Different approaches to address complex problems based on van de Ven et al. (2009). 
(3) Did the students understand the physical footprint and impact on the spatial quality of the linear as well as a proposed CE?

(4) Were students able to describe, understand, and propose an alteration to systemic relationships?

A summary of the student results is publicly available via the REPAiR project webpage (http://h2020repair.eu/ project-results/research-design-studio; http://h2020 repair.eu/wp-content/uploads/2019/03/Deliverable-5.2 -Catalogue-of-solutions-and-strategies-for-Amsterdam. pdf)

\subsection{Urbanism MSc Course "Spatial Strategies for the Global Metropolis"}

As described above, students participating in the regional design studio "Spatial Strategies for the Global Metropolis" were asked to use the concept of CE for the design of a spatial vision and development strategy for AMA. Observations on students' understanding of the concept and their ability to use it to formulate innovative regional design solutions are summarised below. Particular attention is paid to how students' performances were fostered by involving expert knowledge gained during the REPAiR project. Observations draw on an assessment of specifically the 2018 round of the studio. Table 1 lists the titles of students' projects and gives outline information on the CE themes addressed. There were also findings resulting from the experience acquired during earlier rounds of the studio (where the CE concept has not played a role), as well as expert knowledge about regional design.

Students participating in the "Spatial Strategies for the Global Metropolis" studio are expected to ground designs in a comprehensive, evidence-informed understanding of regional spatial structures and development trends. To achieve this goal while using the CE concept, they were asked to conduct a flow analysis during the first stage of their studio work. Outcomes of the analyses indicate that it was relatively easy for students to grasp spatial flows when they were related to the ma-

Table 1. The scope of students' projects.

\begin{tabular}{ll}
\hline Title student project & CE topic \\
\hline Clockwork AMA. Integrating tourism in the CE model by transforming wastescapes & Re-use of land \\
\hline $\begin{array}{l}\text { Closing Loop-Opening up society. Creating an inclusive CE for household } \\
\text { electronics in AMA }\end{array}$ & $\begin{array}{l}\text { Electronic household } \\
\text { waste chains }\end{array}$ \\
\hline Food Island. Building a resilient food system for AMA. & Organic (food) waste chains \\
\hline $\begin{array}{l}\text { Modularama. How modularisation in construction industries can contribute to more } \\
\text { social cohesion }\end{array}$ & Construction and demolition \\
\end{tabular}

Amsterdam's Hill-Sphere(s). Implementing the polycentric model through circular wasted landscapes

Float to Circularity. Connecting human needs with the material flows in the AMA region Re-use of land; Construction and demolition waste chains; Organic (food) waste chains;

\begin{tabular}{ll}
\hline Food Roots. Connecting people and food in a circular agri-food production landscape & Organic (food) waste chains \\
\hline I am De·n·city. Using density to increase liveability & Organic (food) waste chains \\
\hline The Agronomic Renaissance. Towards a fairer and circular agro-food system in the AMA & Organic (food) waste chains \\
\hline $\begin{array}{l}\text { AMA, Balanced. A renewable energy network as a driver for a sustainable } \\
\text { peripheral development }\end{array}$ & Renewable energy
\end{tabular}

Redefining Logistics. How public transport can circularise the flows of goods and Household waste services in the AMA

AMA Activated. Harvesting residual streams to drive peripheral development Renewable energy and food production

The Food Connoisseur. Creating a highly efficient circular foodscape built on global-local synergies

Organic (food) waste chains

Collaborative Commons Scapes. Shifting the AMA system towards a prosuming mindset Sharing economy; solid household waste

AMA-Towards Collective Energy. Increasing social justice in a decentralised energy system

Renewable energy 
terial flows of goods. More complication arose from applying such analysis to the re-use of land and water. In these realms, students struggled in particular with consolidating the CE concept with existing approaches to sustainability, such as urban regeneration and the redevelopment of brownfield sites. Besides understanding their principal logic, students were also asked to map a 'spatial footprint' of current linear and, in the future, more circular waste chains. A broad range of student groups engaged with food and organic waste cycles. This indicates that they found it manageable to identify the spatial implications of a CE in case current linear chains already have a high spatial impact. Finding the spatial expressions of circular construction and demolition waste chains - a chain that is spatially delimited to a few locations-proved most challenging. Few projects discussed these expressions, and if they did so, the discussions concerned indirect outcomes of reformed cycles, e.g., concerning socio-economic relations or new types of housing.

During the initial phase of the studio, apart from analysing flows, students were asked to identify important existing regional spatial structures. The combination of CE-inspired and more traditional analyses-focused on, e.g., transport infrastructure, socio-economic characteristics, and open space-has led to innovative insights into spatial opportunities for a CE in some cases. One project has, for example, associated a concentration of derelict land around a former military defence line in the AMA, with re-use of land strategy that is fostered by tourism. Another project used existing socioeconomic structures (including vocational schools) to inform a more circular use of electronic household waste. Innovation that stems from combining types of analyses is also reflected in re-occurring discussions on decentralisation in students' projects. Finding appropriate planning scales is an important task of regional design. Projects overall demonstrate that the CE concept has led to deeper thinking about a richer set of dependencies in regions and has thus led to new insights regarding the need to up- or down-scale development strategies.

Regional design engages with interdependencies in complex spatial systems. Regional design education, therefore, seeks to train students to deal with a large amount of information comprehensively. When comparing the 2018 students' projects with results from earlier rounds of the studio, it appears that a particular contribution of the CE concept lies in enhanced 'system thinking'. The initial flow analysis forced students to identify specific problems within a broader problem field during an early stage of their project work. The positioning of a distinct problem within a wider system also allowed them to better sustain an argument that ties their vision to their development strategy. Excellent student groups succeeded in supporting an argument with quantitative evidence. CE experts have also perceived the visualisation of students' projects as an innovation.

\subsection{Geodesign for CE in Urban Regions}

As described in Section 3.2, the students in this course modelled different EIS in an urban region, assessing their sustainability impact and using their findings to respond to the complex problems of urban development, encouraging the dialogue between disciplines and allowing a crossover of ideas. The developed EIS proposed a modification of existing value chains, the development of new products, services, and related flows and processes and the spatial configuration and functions of parts of the metropolitan area.

Notably, although using the same methodology, some groups started with a territorially defined challenge, such as the negative environmental and spatial impacts of the parking lots around Schiphol Airport, while others started from a waste flow, such as the large amounts of plastic waste in hospitals. All EIS developed by the students integrated flow as well as territorial aspects. It varies, however, in how far they considered spatial quality in their sustainability assessment. Table 2 briefly describes a selection of EIS, including the territorial and flow aspects tackled, as well as the complexity of disciplinary integration.

The differentiation in the type and quality of the resulting EIS allows us to formulate three main observations on students' understanding of the CE concept and consequently their ability to design EIS.

Firstly, both the complexity and the innovative character of almost all the EIS show how interdisciplinary research and collaboration provided a substantial benefit to the outcomes and the learning process. Students were able to translate their disciplinary perspective and methods into simple concepts while being open to ideas from others. As affirmed by Bridle, Vrieling, Cardillo, Araya and Hinojosa (2013), this willingness and aptitude provide face-to-face exchange and encounters fostering effective communication.

Secondly, each solution simultaneously addresses one or more issues, tackling specific parts of the waste flows in a holistic way, such as the building insulation material, organic food waste stream, and underused spaces. By developing EIS, students acquired a systematic design approach in a 'learning-by-doing' way. This approach allowed them to consider the effects of the interaction of different systems by focusing on larger-scale dynamics and observing their spatial effect. For instance, in the case of the MYC block solution, students propose to develop a biodegradable insulation material made out of fibres and mycelium fungi and based on already existing patents. Although the solution in itself is not new, the innovative character lies in the local production of fibres like reeds on unused (waste)land alongside specific canals in the AMA. A secondary systemic effect of this cultivation is the prevention of the salinization and subsidence of agricultural land, currently affecting parts of the AMA (OECD, 2017). 
Table 2. EIS, their territorial and flow aspect, and the complexity of their integration.

\begin{tabular}{|c|c|c|c|}
\hline Title & Territorial aspect(s) & Flow aspect(s) & Complexity of integration \\
\hline $\begin{array}{l}\text { Bio-seasonal parking; } \\
\text { transforming seasonally } \\
\text { underused car parks of the } \\
\text { International Amsterdam } \\
\text { Airport Schiphol into } \\
\text { productive landscapes }\end{array}$ & $\begin{array}{l}\text { Low spatial quality and } \\
\text { negative effects on the } \\
\text { ecological connectivity of } \\
\text { large parking lots. }\end{array}$ & $\begin{array}{l}\text { Food waste used as } \\
\text { secondary raw material for } \\
\text { the production of } \\
\text { biodegradable asphalt } \\
\text { alternatives }\end{array}$ & $\begin{array}{l}\text { Product development to } \\
\text { agricultural practices and } \\
\text { spatial design of parking } \\
\text { areas. }\end{array}$ \\
\hline $\begin{array}{l}\text { Mycelium (MYC) Blocks; } \\
\text { new bio-isolation materials } \\
\text { made out of plant fibres } \\
\text { and fungi }\end{array}$ & $\begin{array}{l}\text { Need for sustainable } \\
\text { insulation material for the } \\
\text { refurbishment of post-war } \\
\text { neighbourhoods; Use of } \\
\text { salinated and polluted areas } \\
\text { for the growth of fibres. }\end{array}$ & $\begin{array}{l}\text { Bio-based insulation } \\
\text { material, agricultural } \\
\text { wastewater cycle and food } \\
\text { waste cycle }\end{array}$ & $\begin{array}{l}\text { Product design, value chain } \\
\text { design, and integration of } \\
\text { spatial quality into } \\
\text { environmental } \\
\text { considerations }\end{array}$ \\
\hline $\begin{array}{l}\text { Enzymatic fuel cell; using } \\
\text { neighbourhood extension } \\
\text { project to store energy in } \\
\text { public space }\end{array}$ & $\begin{array}{l}\text { Multifunctional use of } \\
\text { public spaces }\end{array}$ & Energy and food waste & $\begin{array}{l}\text { Technology readiness } \\
\text { assessment and spatial } \\
\text { quality of its application on } \\
\text { the neighbourhood scale }\end{array}$ \\
\hline $\begin{array}{l}\text { Greening up the city: a new } \\
\text { solution for regenerative } \\
\text { green facades }\end{array}$ & $\begin{array}{l}\text { Negative environmental, } \\
\text { health, and spatial impact } \\
\text { of areas with a high level of } \\
\text { impermeable surfaces }\end{array}$ & $\begin{array}{l}\text { Organic waste for bioplastic } \\
\text { production }\end{array}$ & $\begin{array}{l}\text { Product development and } \\
\text { building and planning } \\
\text { regulations }\end{array}$ \\
\hline $\begin{array}{l}\text { Food Waste Insect Protein; } \\
\text { Biowaste collectors with } \\
\text { insect larvae to provide } \\
\text { local farming fodder }\end{array}$ & $\begin{array}{l}\text { Neighbourhood as an ideal } \\
\text { collection scale for } \\
\text { collecting food waste }\end{array}$ & $\begin{array}{l}\text { Use insects to cycle food } \\
\text { (waste) and provide nearby } \\
\text { farms with animal fodder }\end{array}$ & $\begin{array}{l}\text { Healthy and safe product } \\
\text { development and collection } \\
\text { strategy }\end{array}$ \\
\hline $\begin{array}{l}\text { Hospital bioplastic; Circular } \\
\text { use of plastics in hospitals }\end{array}$ & $\begin{array}{l}\text { The regional network of } \\
\text { hospitals, waste processing } \\
\text { facilities, and bioplastic } \\
\text { production }\end{array}$ & $\begin{array}{l}\text { Plastic recycling with } \\
\text { specific material } \\
\text { requirements }\end{array}$ & $\begin{array}{l}\text { Chemical processes and } \\
\text { geographic network } \\
\text { analysis }\end{array}$ \\
\hline
\end{tabular}

If some solutions initially addressed circularity at the product level, others began by observing the spatial dynamics and territorial effects of a linear economy. The bio-seasonal parking EIS reflects on how to reclaim underused parking lots near the Schiphol airport. Students began by designing a biodegradable membrane that can substitute the conventional bitumen and secondly a specific urban structure of the car park to guarantee the water infiltration and avoid oil percolation. In this way, the solution allows to have temporary parking areas during specific months and to grow crops in the remaining months.

Eventually, through the development of EIS, students reflected on the partial implication of CE. From the results, it was clear that some students had had difficulties in understanding land as a resource and urban territories as ecosystems, going beyond the idea of space as a support for allocating products and functions. The limitation experienced by the students underlines the argument expressed by Williams (2019) regarding the inadequacy of the current conceptualisation of CE when applied to urban territories: "a circular city is about a great deal more than creating a CE and circular business models within the urban context. It is about the regeneration and renewal of complex urban ecosystems" (Williams, 2019, p. 15).

\section{Validation of Study Outcomes by Students and Stakeholders of the CE Transition}

Collaboration between university and practice is not new to design education. However, such collaboration is often dependent on a certain number of highly-motivated professionals. Very often, a structural perspective on regional collaboration in education is lacking (Ministry of Education, Culture and Science, 2015). In these two cases, the parties collaborating in the courses through the REPAiR project have a more collective motivation to, on the one hand, make a broader use of the knowledge available for students; on the other hand, to seek innovation via the interaction amongst students, teachers, and stakeholders who are involved in practice in the region. From the perspective of knowledge generation, students and teachers in the university are also seen as stakeholders in the region, contributing to its transition towards a CE. To validate the outcome of the teaching experiments, the authors collected feedback from all parties involved in such a situated learning environment. Due to 
the different settings of the two courses, the feedback was collected through various channels, including questionnaires distributed by student organisations, tutors' meetings, and interviews with stakeholders.

\subsection{Feedback from Students, Teachers and Practitioners on the Regional Design Course}

Every year, when the course is finished, questionnaires are distributed by the Urbanism student association POLIS to evaluate teaching quality. For this article, we used the reports of the past two years (2017 and 2018), when the collaboration with the REPAiR project was implemented.

In response to how did the lectures and workshops support or improve your understanding of the concept of flows and circular economy within a region, feedback shows that the workshop given by the REPAiR team on material flow analysis provided great help to students to break the CE concept down. However, students felt that such knowledge and skills are very basic or general. It would be more helpful if experts of respective flows (energy, waste, water, and so on) could give in-depth lectures. Or in other words, expertise from other disciplines is needed to facilitate real interdisciplinary work.

CE was a new topic for both tutors and students. Generally speaking, students liked to deal with a topic that they had not studied before and learnt a great deal from this topic, especially how it can be reflected in spatial visions and strategies. However, some students found the focus on CE to be a bit demanding.

\subsection{Stakeholder Evaluation of the EIS Developed by the Students During the Geodesign for a CE in Urban Regions Course}

On 18 September 2018, a PULL workshop was held in Amsterdam with 19 stakeholders. One part was dedicated to further develop EIS for the AMA. The EIS developed by the students in the geodesign course was used as one of the input sources (see Table 2). Other solutions were based on literature studies and pilot projects, or co-developed by the stakeholders themselves in earlier workshops.

Participants of the workshop included local authorities, policymakers, local business representatives, and international partners of the REPAiR consortium. The EIS were co-developed in separate worktables. The workshop participants were asked to select a draft solution and continue to develop that solution towards a more detailed and implementable solution. In a post-workshop survey, the participants were asked questions regarding their perception of the usefulness of the EIS developed in the workshop with regards to the CE objectives in the AMA. The participants were asked to rate the likelihood of the EIS, which they helped co-develop in the workshop, to help address the specific objectives for each CE topic in the AMA. For each CE objective in the AMA, par- ticipants rated the impact of each co-developed EIS from 1 to 5 , with 1 being "very likely to address the objective" and 5 being "very unlikely to address the objective".

Detailed results of the questionnaire are reported in Remoy, Arciniegas et al. (2018).

The results can be summarised as follows:

(1) Concerning the objectives related to the redevelopment of wastescapes, the students' EIS were assessed as either "very likely" or "neutral" to contribute to the objectives. For some objectives like the redevelopment of wastescapes around Schiphol, the student EIS scored best. For the objective of creating trust and collaboration among stakeholders, the student EIS scored worst. The average value of non-student EIS overall objectives was 2.37 , the best value was 1.89 , and the worst was 3.10 . The best student EIS score was 1.67 , the worst 3.20, and the average 2.36;

(2) Concerning the objectives related to the food waste value chain, the student EIS were assessed as rather likely to contribute to the objectives. The average value of non-student EIS overall objectives was 2.31; the best value was 1.50 the worst 3.1. The best students EIS score was 1.50, the worst 2.0, and the average 1.87. The students' EIS were for neither objective the best nor worst scoring EIS;

(3) Concerning the objectives related to the construction and demolition waste value chain, the student EIS were assessed as "very" to "rather likely" to contribute to the objectives. The average value of non-student EIS overall objectives was 2.35. The best value was 1.00 , the worst 4.00 . The best student EIS score was 1.00 , the worst 2.59, and the average 1.86. The students' EIS were for neither objective the best nor worst scoring EIS;

(4) To summarise, the EIS developed by the students during the course were seen at least as likely to contribute to addressing the defined challenges as those EIS that were co-developed by stakeholders in the area. Furthermore, most of the student solutions were considered more likely to contribute to the solutions than solutions based on pilot and literature studies from other places.

\section{Discussion and Conclusions}

In order to use the CE concept for a regional design, students had to integrate the concept with other, more traditional regional-design approaches to influencing the morphology of regional urbanisation and socioeconomic functional relations, for instance. In most cases, students facilitated the CE concept through the association, or 'sampling', of classical and new themes. Outcomes of these combinations can be considered inspirational. Few projects, however, reached a deeper level of conceptual integration, expressed in verifiable interdependencies between issues from thematic fields. 
In this context, it is important to consider the little time the students had to develop their projects (10 weeks). REPAiR experts tutoring student groups and providing extra workshops enhanced the quality of the projects, and the rich material in terms of policy documents (visions, agendas, and reports) supported the practical application of the CE concept.

The integration of the courses into the living lab activities had significant advantages. First, the students started with objectives formulated by real stakeholders, with the usual issues that they are often very vague and sometimes contradicting. A further advantage was that the students also had the possibility to present and discuss their results with the stakeholders during living lab workshops. This means that, specifically in the Geodesign course, the integration of research and design education provided the students with a situated and indeed transdisciplinary learning environment. The fact that the course is an elective course with a low number of students from different MSc programmes supported this learning effect. Achieving the same in a core course of a single MSc programme with a large number of students from one programme only is probably much more difficult and would require a rather radical redesign of several master programmes, which may take longer than externally funded on-going research projects.

One clear effect of the integration of the CE concept into teaching was that the students understood that they needed to address challenges from a systemic perspective rather early into the design process. They had to understand and distinguish the relations between different subsystems and their spatial structures. The students were faster than usual to relate specific and local problems of the linear economy within the wider economic and spatial system. This led to design proposals that went beyond problem-fixing at specific locations towards design proposals that discussed transitions and disruption and the role of regional structures and stakeholders within these processes.

A crucial outcome for regional planning and design practice and research was that the students' work amplified the need to work with scales and to reconsider the definition of a region. This working with scales is crucial for regional planning, where functional relations, predominantly commuting patterns, are often used to define borders of regions while ignoring flow relations that go beyond those limits. It is equally important for lifecycle-based sustainability assessments, which are often based on functional units that refer to administrative areas, such as municipality boundaries. Furthermore, it is a crucial shortcoming to ignore the complexity of the territorial metabolism of urban regions.

Finally, we are compelled to state that the integration of research and education was staff-intensive and thus required a higher teacher-to-student ratio than usual. Moreover, it asked for a high level of engagement and flexibility of the teaching staff. This engagement is a vital aspect when aiming to integrate research and edu- cation, considering that many universities in Europe are under financial pressure and that teaching loads are on the rise. Therefore, when aiming at the integration of research and design education, it is crucial that, at the time of writing a research proposal, budget and time requirements of staff involvement are already considered in the budget planning. Furthermore, teaching schedules are rather rigid and often defined a year in advance, which also needs consideration in the research design. It is absolutely advantageous if already existing courses have a clear structure, precisely defined learning goals, and required products that fit the research questions and the tasks of the research projects.

Moreover, clear transparency towards the students is important. Students need to be made aware that both the lectures they attend and the materials they receive constitute work in progress, and that the staff that provides workshops and feedback are not primarily trained as teachers. Students also need to be made aware of the ethical aspects of participating in a research project, such as how to deal with confidential data or working with results that are not yet published by the research team. The same holds for the researchers, who have to be ethical when using student work in further research activities and publications, and conscious that the grades of the students cannot be dependent on the value their work has for the research project, but rather on the general learning goals of the course.

If the above is considered well in advance then, according to our experience, the following aspects are crucial for successful integration: making sure that the teachers who are not experts in the added field of expertise are informed and educated in a way that they are comfortable enough to do their job; providing both additional workshops and lectures from the research team as well as stakeholder involvement in a structured way and at times when it fits naturally in the design process followed by the students; and finally, evaluating the course process and outcomes through feedback from students, teachers, and stakeholders, critically reflecting on these evaluations, and adapting the course if necessary.

\section{Acknowledgments}

We want to thank the students and colleagues from the Department of Urbanism at the Faculty of Architecture and the Built Environment at Delft University of technology for participating in the course and being open to joining the experiment of integrating a research project into teaching activities. We are grateful for the feedback and contributions of the stakeholders of the REPAiR PULL. We want to thank the whole REPAiR Team, in particular to UNINA and HCU Research teams for organising the international student workshops. Funding: This research was conducted within the framework of the European Horizon 2020 funded research "REPAiR: REsource Management in Peri-urban AReas: Going Beyond Urban Metabolism". This project 
has received funding from the European Union's Horizon 2020 research and innovation programme under grant agreement no 688920. This article reflects only the author's view. The Commission is not responsible for any use of the information contained therein.

\section{Conflict of Interests}

The authors declare no conflict of interests.

\section{References}

Baccini, P., \& Oswald, F. (2008). Designing the urban: Linking physiology and morphology. In G. Hirsch Hadorn, H. Hoffmann-Riem, S. Biber-Klemm, W. Grossenbacher-Mansuy, D. Joye, C. Pohl, ... E. Zemp (Eds.), Handbook of transdisciplinary research (pp. 79-88). Dordrecht: Springer.

Bridle, H., Vrieling, A., Cardillo, M., Araya, Y., \& Hinojosa, L. (2013). Preparing for an interdisciplinary future: $A$ perspective from early-career researchers. Futures, 53, 22-32. https://doi.org/10.1016/J.FUTURES.2013. 09.003

Dehaene, M. (2018). Horizontal metropolis: Issues and challenges of a new urban ecology statements. In P. Viganò, C. Cavalieri, \& M. Barcelloni Corte (Eds.), The horizontal metropolis between urbanism and urbanization (pp. 269-282). Cham: Springer. https://doi. org/https://doi.org/10.1007/978-3-319-75975-3

De Hei, M. (2016). Collaborative learning in higher education: Design, implementation and evaluation of group learning activities (Unpublished PhD dissertation). Leiden University Graduate School of Teaching, Uitgeverij BOXpress.

EC. (2011). Communication from the Commission to the European Parliament, the Council, the European Economic and Social Committee and the Committee of the Regions "Roadmap to a Resource Efficient Europe". EUR-Lex. Retrieved from https://eur-lex.europa.eu/legal-content/EN/TXT/ ?uri=CELEX\%3A52011DC0571

Geldermans, R. J., \& Taelman, S. (2016). REPAiRREsource management in peri-urban areas: Definition of circular economy. Delft University of Technology. Unpublished manuscript.

Lave, J., \& Wenger, E. (1991). Situated learning. Legitimate peripheral participation. Cambridge: University of Cambridge Press.

Lawson, B., \& Dorst, K. (2009). Design expertise. Oxford: Architectural Press.

Ministry of Education, Culture and Science. (2015). The value of knowledge: Strategic agenda for higher ed- ucation and research 2015-2025. The Hague: Directorate of Higher Education and Student Grants.

Müller, D. B., Tjallingii, S. P., \& Canters, K. J. (2005). A transdisciplinary learning approach to foster convergence of design, science and deliberation in urban and regional planning. Systems Research and Behavioural Science, 22, 193-208.

OECD. (2017). The governance of land use in the Netherlands: The case of Amsterdam. Paris: OECD Publishing. https://doi.org/http://dx.doi.org?10.1787/ 9789264274648-en

Remoy, H., Arciniegas, G., Furlan, C., Wandl, A., Amenta, L., Šileryte, R., . . van Timmeren, A. (2018). REPAiR AMA 3rd PULL workshop report. Delft: REPAiR, Delft University of Technology.

Remoy, H., Furlan, C., Wandl, A., Dabrowski, M., Amenta, L., Arciniegas, G., . . Šileryté, R. (2018). REPAiR Catalogue of solutions and strategies for Amsterdam. Deliverable 5.2. Delft: REPAiR, Delft University of Technology.

Russo, M., Amenta, L., Attademo, A., Cerreta, M., Formato, E., Remoy, H., . . . Varjú, V. (2016). Deliverable 5.1-Handbook peri-urban living labs. Delft: REPAiR, Delft University of Technology.

Schweitzer, L. A., Howard, E. J., \& Doran, I. (2008). Planners learning and creating power: A community of practice approach. Journal of Planning Education and Research, 28, 50-60.

Steen, K., \& van Bueren, E. (2017). The defining characteristics of urban living labs. Technology Innovation Management Review, 7(7), 21-33.

Steinitz, C. (2012). A framework for geodesign: Changing geography by design. Redlands, CA: ESRI Press.

Taelman, S., Tonini, D., Wandl, A., \& Dewulf, J. (2018). A holistic sustainability framework for waste management in European cities: Concept development. Sustainability, 10(7), 2184. https://doi.org/10.3390/ su10072184

van der Leer, J., van Timmeren, A., \& Wandl, A. (2018). Social-ecological-technical systems in urban planning for a circular economy: An opportunity for horizontal integration. Architectural Science Review, 61(5), 298-304. https://doi.org/10.1080/00038628. 2018.1505598

van de Ven, F. H. M., Gehrels, H., van Meerten, H., van de Pas, B., Ruijgh, E., Vatvani, D., . . . van der Linden, T. (2009). Land \& water management in the urban environment. Delft and Utrecht: Deltares.

Williams, J. (2019). Circular cities. Urban Studies. Advance online publication. https://doi.org/10.1177/ 0042098018806133 


\section{About the Authors}

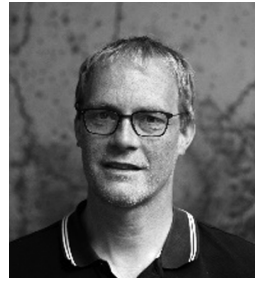

Alexander Wandl (MSc) is an Urbanist and Senior Researcher of Environmental Technology and Design, at the Faculty of Architecture and the Built Environment. His research focuses on developing sustainable urbanisation, using an extended territorial metabolism approach and integrating (GIS-supported) methods and tools from different disciplines. As scientific coordinator of the Horizon 2020 Funded Research Project Repair-Resource Management in Peri-Urban Areas-he is at the forefront of developing spatial strategies which support the transition towards more circularity. He specifically focuses on the challenges related to the sustainable development of dispersed urban areas and periurbanisation processes in Europe.

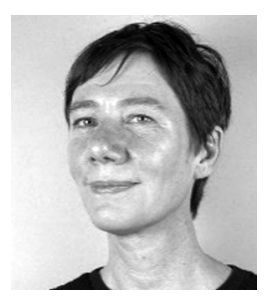

Verena Balz (Dr.ir.) is a Teacher and Researcher at the Department of Urbanism, Delft University of Technology. The main focus of her research is on the use and performance of regional design-led approaches in planning decision-making. Her work on this topic builds upon her professional experience as a senior urbanist and has been published in international peer-reviewed journals and academic books. As a teacher and coordinator, she is involved in several Master of Architecture, Urbanism, and Building Sciences programmes.

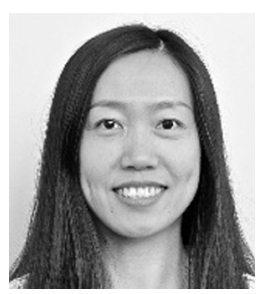

Lei Qu (Dr) is an Assistant Professor at Delft University of Technology. She studied in Tsinghua University in China from 1994 to 1999 (Bachelor of Architecture), and later on obtained a master's degree and PhD in Urban Planning and Design in the same University (2004). Her work at TU Delft involves coordinating and teaching in Research \& Design Studios and Graduation Lab for Master students, supervision of PhD candidates, research on comparative studies between European and Chinese urban and regional development.

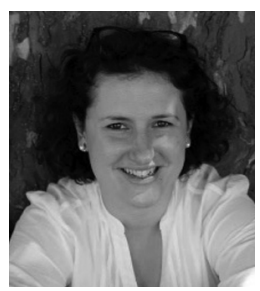

Cecilia Furlan (Arch. Dr) is a Post-Doctoral Researcher at the Department of Urbanism, Delft University of Technology. Cecilia's interest focuses on urban design and urban planning strategies for sustainability and circularity, with particular focus on sustainable urban development under conditions of resource scarcity. She believes that cities can do more with less, working towards sustainable growth. Over the past years, she has worked and taught in different architecture and urbanism schools across Europe.

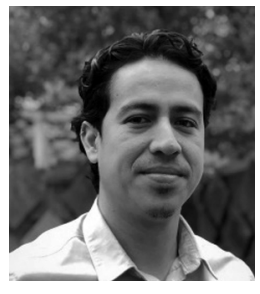

Gustavo Arciniegas (Dr) is the Lead Consultant and Director of Geo-Col GIS and collaborative planning, a Netherlands-based consultancy firm specialising in collaborative GIS, Geodesign, sustainable spatial planning, and Planning Support Systems that include collaborative instruments (hardware + processware). His background is in Geoinformatics and he holds a PhD in map-based decision support tools for collaborative planning. He is currently a Guest Researcher of Environmental Technology and Design, Department of Urbanism, Faculty of Architecture and the Built Environment, Delft University of Technology, where he collaborates within the Horizon 2020 REPAiR project, which focuses on integrating Geodesign, Life Cycle Analysis, Sustainability Assessment, and Living Labs for improving waste management in European cities.

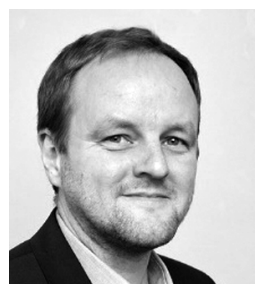

Ulf Hackauf (MSc) worked for several years as Project Architect on various international projects before joining the Delft University of Technology as teacher and researcher. From 2008 to 2014, he was part of The Why Factory, a group led by acclaimed architect Winy Maas that explores future urban scenarios. Since 2015, he is in the subject of Environmental Technology and Design, where he focuses on the relation between urban metabolism and the design of urban environments. 